Mykytenko Lyudmila,

$\mathrm{PhD}$ (Law Sciences), Associate Professor, Kyiv National University of Trade and Economics, 19, Kyoto str., Kyiv, 02156, Ukraine

ORCID: 0000-0002-5365-3377

Researcher ID: M-2285-2016

\title{
REALIZATION OF CONSUMER RIGHTS IN HOUSING AND UTILITIES AREA
}

The terminological inconsistency in the legislation on housing and communal services is analyzed. The normatively developed concept has been researched and it is established that there is a certain legal uncertainty which limits the rights of consumers, in particular, the notion of «management of an apartment building» is not regulated and it is not specified who is granted this right; abolished the legislative concept «the right of co-owners of apartment buildings to manage their property». The definition of the status of the consumer as an individual receiving services in the housing and communal sphere is analyzed.

Keywords: consumer rights protection, manager, services, house keeping, coowner.

Микитенко Людмила. Реалізація прав споживачів у жситлово-комунальній сфері.

Проаналізовано термінологічну неузгодженість в законодавстві про житлово-комунальні послуги. Досліджено нормативно розроблену конщепџію та встановлено, що існує певна юридична невизначеність, яка обмежує права споживачів, зокрема, не впорядковано поняття «управління багатоквартирним будинком» та не конкретизовано кому надається це право; скасовано законодавче поняття «право співвласників багатоквартирних будинків управляти своїм майном». Проаналізовано визначення статусу спожсивача як фізичної особи, яка отримує послуги в житлово-комунальній сфері.

Ключові слова: захист прав споживачів, управитель, послуги, утримання будинків, співвласник.

Relevance of the research topic. Chapter 20 «Consumer rights Protection» of the EU-Ukraine Association Agreement establishes that Ukraine is gradually approximating its legislation to the EU acquis by introducing a number of relevant EU Directives. European consumer policy is based on the approach that legal regulation of consumer rights protection plays an increasingly important role. 
In the current conditions of rapid development of economic processes and fierce competition among business entities, consumer legislation is a basic element of such development. Consumer is recognized as a non-professional, who purchases goods and services to meet personal needs, and therefore needs to protect his or her rights from the state side to ensure a balance of interests in market relations with a more powerful participant - the entrepreneurship.

These tasks are extremely important for the consumer community in Ukraine. The entry into force on May 1, 2019 of the Law of Ukraine «On Housing and Public Services» No. 2189-VIII of 09.11.2017, as amended by Law No. 2454-VIII of 07.06.2018 (hereinafter the Law) (Zakon Ukrainy «Pro zhytlovo-komunalni posluhy, 2017), caused violation of this Law, and other related legal acts, consumer rights and provisions of the Constitution of Ukraine. in return the Law on Housing and Public Services (as well as other laws and documents) introduces concepts that are contrary to the Constitution and restrict consumer rights.

The Constitution of Ukraine (Article 22) states - «Constitutional rights and freedoms are guaranteed and cannot be abolished. When adopting new laws or amending the existing laws, it is not allowed to narrow the content and scope of existing rights and freedoms» (Zakon Ukrainy «Konstytutsiia Ukrainy», 2006).

Formulation of the problem. In accordance with the Law of Ukraine «On Consumer Protection» (Zakon Ukrainy «Pro zakhyst prav spozhyvachiv», 1991), all citizens of Ukraine have the right to receive services in full and proper quality. However, in the housing and communal sector, consumer rights are often violated due to legislative disorder and uncertainty.

The Law of Ukraine «Housing and Services» defines that housing and communal services are the result of economic activity aimed at providing living conditions for people in residential and non-residential premises, houses and buildings, complexes of buildings in accordance with norms, standards, rules and policies.

A contractor is recognized as an entity whose subject of activity is the provision of housing and communal services to the consumer in accordance with the terms of the contract.

Currently, there is some ambiguity in the legislation on housing and utilities that limits consumer rights. In particular, there is the certain ambiguity in the defenition of «management of an apartment building» and to whom this right is granted, as well as the term in the legislation «the right of co-owners of apartment buildings to manage their property» are not regulated. In addition, the cornerstone is the definition of the status of the consumer as an individualmreceiving services in the housing and communal sphere, which requires the legal regulation of the concept of «management of an a

Analysis of recent researches and publications. Questions about legal problems of housing and public legislation were addressed by: V. Alekseeva (Aleksieieva, 2005), O. Dimchenko (Dymchenko, 2009), I. Dragan (Drahan, 2011), 
O. Malyuta (Maliuta, 2010), V. Rybachuk (Rybachuk, 2012), A. Sidorova (Sydorova, 2012), V. Shumilkin (Shumilikin, 2003), and others. But in their works, the role of state authorities in developing strategies for the development and management of housing and public services at the national, regional and local levels were only highlighted.

To study the legal problems of applying the current legislation in the housing and public sphere, the following tasks were set:

- to define the relation of concepts: «consumer», «person», «citizen», «individual» for further regulation of the legislation;

- to outline the terminological inconsistency of concepts in the housing and communal sphere;

- to make conclusions and proposals for improving legislation in this area.

Presenting main material. The Constitution of Ukraine in Art. 8 guarantees of protection of human and citizen's rights and freedoms are established. The rules that enshrine the rights and interests of individuals are the basis for detailing them in sectoral legislation and regulating all legal relationships, specifying the content of legal guarantees of realization, as well as for establishing a procedural process for the protection of subjective property and personal non-property rights protected by the law of interests and freedoms., including by means of civil procedural law.

However, in the definition of the term «individual», the Constitution does not contain the concept of «individual», but there is the concept of «person», «citizen», «resident». The status of «individual» is the status of a slave, not a person - a material body without spiritual components, a user of property, not his master, a person who has no relation to the constitutional right under Art. 6 of the Charter of the Universal Declaration of Human Rights.

In 1977, the General Assembly of the United Nations gave the following definition of the term «individual - non-citizen» (Deklaratsiia Orhanizatsii Obiednanykh Natsii, 1984). Private international law (Chapter 6, paragraph 1) accepts that «an individual is a migrant», that is, a person who has no legal connection with the state and therefore does not own it.

According to the passport, the person of Ukraine is a citizen, not an individual, the passport has a series and a number that fully identify the person.

The Civil Code of Ukraine (Article 24, Part 1) also stipulates that «a person, as a party of civil relations, is considered an individual». Since a person is always a party of any civil relationship, including before birth and some time after death, to regard the person as an «individual» is unconstitutional.

All people in Ukraine are consumers in different ways. In the first editions of the Law of Ukraine «On Consumer Protection», effective from October 1, 1991 and from December 15, 1993, the consumer was defined as a «citizen», but in subsequent revisions - already as a «individual», so all consumers in Ukraine this law deprived the title of «human» and «citizen». 
The manipulation in the legislation of Ukraine of people by means of degrading status is a crime, genocide against a person (Article 442 of the Criminal Code of Ukraine) (Zakon Ukrainy «Kryminalnyi kodeks Ukrainy», 2001).

The next thing that needs to be regulated is the concept of managing an apartment building. In the previous edition of the Law of Ukraine «On Housing and Public Services», which became invalid with the adoption of the new Law, the categories of «holder» and " manager»of an apartment building and their functions were defined, in particular: Art. 13, Part 1:

2) maintenance of buildings and structures and adjoining territories (cleaning of internal premises and adjoining territories, sanitary-engineering services, maintenance of internal-house networks, maintenance of elevators, illumination of places of common use, routine repair, removal of household waste, etc.);

3) services for managing a house, structure or group of houses (balancing, contracting for the performance of services, monitoring the fulfillment of the terms of the contract, etc.);

4) repair of premises, buildings, structures (replacement and reinforcement of structural elements and networks, their reconstruction, restoration of load-bearing capacity of load-bearing structural elements, etc.) (Zakon Ukrainy «Pro zhytlovokomunalni posluhy», 2017).

In the new edition of the Law of Ukraine «On Housing and Public Services»: Art. 1, h. 12) apartment building management service - the result of economic activity of economic entities aimed at ensuring the proper living conditions and meeting the household needs of the residents of the house by maintaining and repairing the joint property of the apartment building and its territory in accordance with the terms of the contract.

In Art. 1, part 14 of the Law of Ukraine «On Housing and Public Services» the manager of an apartment building (hereinafter - the manager) - an individual - an entrepreneur or a legal entity - the subject of business activity, which under the contract with the co-owners provides the proper maintenance and repair of the joint property of the apartment home and adjoining territory and proper living conditions and household needs (Zakon Ukrainy «Pro zhytlovo-komunalni posluhy, 2017).

So, in the new Law of Ukraine «On Housing and Public Services» (Article 1, Part 1, Item 14 and Article 2 Part 1), the category «holder» was abolished and the function of «maintenance» was defined as «management.», in particular, the subject of the regulation, defined by the Law, is» relationships arising in the process of providing consumers with services for managing an apartment building», not maintenance services.

In addition, in the current Law of Ukraine «On the peculiarities of exercising the property right in an apartment building» № 417-VIII with the changes made in accordance with the Law № 2189-VIII of 09.11.2017 defined the following: 
- Art. 1, item 8 - management of an apartment building - committing to the owners of an apartment building actions to exercise the rights and fulfill the obligations of the co-owners in connection with owning, using and managing the joint property of an apartment building;

- item 1, item 7 - manager of apartment building (hereinafter - manager) individual - entrepreneur or legal entity - subject of business activity, which by agreement with the co-owners ensures proper maintenance and repair of joint property of apartment building and adjoining territory and adequate living conditions and satisfaction of household needs (Zakon Ukrainy «Pro osoblyvosti zdiisnennia prava vlasnosti u bahatokvartyrnomu budynku, 2015).

However, since «management» (p. 8) is the actions of co-owners - owners, users and managers of property and no one else, co-owners are «managers» because they have the right to govern. And the «manager», who «by agreement with the co-owners, ensures the proper maintenance and repair» of the joint property (item 7), is not the manager, but is the «holder».

Thus, the co-owners of apartment buildings (which are managers of common property and consumers of public services including) in violation of the Constitution of Ukraine (Article 22) have been deprived of the constitutional right to be the manager and to own, use and dispose of their own property.

The concept of «co-owner's share in the cost of maintaining and repairing common property» leads to a double interpretation.

The share of the co-owner in the costs of maintaining and repairing the joint property is defined in the Law of Ukraine «On peculiarities of exercising the property right in an apartment building» № 417-VII (Article 1, item 9) and other acts depending on the area of the apartment and / or non-residential premises of the co-owner.

These costs cannot depend on the area of the apartment and / or non-residential premises (because the property is common), so the costs should be divided equally by the number of owners of apartments and / or non-residential premises located in the apartment building.

Attention should also be drawn to the legal ambiguity of the concept of «housing and utilities contracts». The Law of Ukraine «On Housing and Communal Services» No. 2189-VIII of 09.11.2017 (as amended by Law No. 2454-VIII of 07.06.2018) states that: Art. 1, part 1, item 5 - housing and communal services - the result of economic activity aimed at providing living conditions and / or stay of persons in residential and non-residential premises, buildings and buildings, complexes of buildings and structures in accordance with standards, norms, standards, the rules and regulations implemented on the basis of relevant contracts for the provision of housing and communal services.

In Art. 1, part 1, clause 6 of the Law of Ukraine «On Housing and Communal Services» - individual consumer (who I am) - an individual who is the owner (co-owner) of real estate, or with the consent of the owner, another person who uses 
the real estate and receives housing and communal services for their own needs and with which or on whose behalf the relevant contract for the provision of housing and communal services is concluded.

Under the management of an apartment building in accordance with Art. 1, part 1, clause 12 of the Law of Ukraine «On Housing and Communal Services» is understood - the result of economic activity of economic entities aimed at ensuring the proper living conditions and meeting the household needs of residents by maintaining and repairing joint property of an apartment building and its suburban territory in accordance with the terms of the contract. Provision of housing and communal services is carried out solely on a contractual basis.

Thus, the Law states that: - management services are provided in accordance with the terms of the contract with the owner (individual consumer of services); - with the consent of the owner, it is permissible to conclude a contract with another person who uses the real estate object and receives housing and communal services for his own needs. Instead, the same Law (Article 15, Part 1, Item 2 and Final Provisions) establishes the procedure for concluding, amending and terminating contracts for the management of an apartment building, whereby the contract is concluded on behalf of the co-owners of the apartment building by an authorized person of a local government body.

Conclusion. Thus, in view of certain problems of terminological inconsistency of concepts in the housing and communal sphere, we have identified the main factors that should be regulated, namely:

- the individual consumer-owner is deprived of the right to enter into a public utility service contract;

- this right is usurped, by granting it without the owner's consent to an authorized person of a local self-government body, who cannot have such a right, because he does not use the real estate object and does not receive housing and communal services for his own needs;

- violated the requirements of Art. 4 (h. 3) of the Law of Ukraine «On Housing and Communal Services», which defines the powers of local self-government bodies and which it does not provide for the conclusion of an agreement on behalf of the co-owners of an apartment building.

We will note that these norms violate Art. 22 of the Constitution of Ukraine, which does not allow the content and scope of existing rights and freedoms to be narrowed, «and the requirements of the basic act of the civil legislation of Ukraine the Civil Code of Ukraine (Article 4, Part 2), in particular Art. 633 (part 4), which states that «An entrepreneur is not entitled to refuse to conclude a public contract if he has the opportunity to provide the consumer with the relevant goods (works, services).

In case of unjustified refusal of the entrepreneur to conclude a public contract, he must compensate the losses caused to the consumer by such refusal.

It is considered appropriate to amend the following legal acts: 
1. Abolish in the Legislation of Ukraine the term and concepts of «natural person» as unconstitutional and degrading, and replace them with the constitutional terms and concepts of «man», «citizen» and «resident»;

2. In the Laws of Ukraine «On Housing and Communal Services № 2189-VIII of 09.11.2017 (as amended in accordance with Law No. 2454-VIII of 07.06.2018)» and «On Features of Exercising Ownership Rights in an Apartment Building» No. 417-VIII (as amended by Law No. 2189-VIII of 09/11/2017), which abolished the right of co-owners of apartment buildings to manage their property, the term «manager» (which «by agreement with the co-owners ensures the proper maintenance and repair» of joint property) replace by the term «holder».

3. Clause 9 of Article 1 of the Law «On peculiarities of exercising the right of ownership in an apartment building» № 417-VII shall be revised as follows: or nonresidential premises.

4. In the Law «On Housing and Communal Services» No. 2189-VIII of 09.11.2017 with the changes made in accordance with Law No. 2454-VIII of 07.06.2018 the provisions of Art. 15, Part 1, Item 2 and the Final Provisions establishing the procedure for concluding, amending and terminating contracts for the management of an apartment building in which «the agreement is concluded on behalf of the co-owners of the apartment building by an authorized person of the local government» shall be canceled as unconstitutional and such that deprives the individual consumer of the homeowner of the right to enter into a public utility contract.

\section{REFERENCES}

1. Zakon Ukrainy «Pro zhytlovo-komunalni posluhy» № 2189-VIII vid 09.11.2017 [Law of Ukraine «On ratification of the Protocol on Pollutant Release and Transfer Registers»]. (n.d.) zakon.rada.gov.ua. Retrieved from: https://zakon.rada. gov.ua/laws/show/2189-19 [in Ukrainian].

2. Zakon Ukrainy «Konstytutsiia Ukrainy» № 254k/96-VR vid 28.06. Law of Ukraine «On ratification of the Protocol on Pollutant Release and Transfer Registers»]. (n.d.) zakon.rada.gov.ua. Retrieved from: http://zakon2.rada.gov.ua/laws/show/ 254\%D0\%BA/96\%D0\%B2\%D1\%80 [in Ukrainian].

3. Zakon Ukrainy «Pro zakhyst prav spozhyvachiv» № 1023-XII vid 12.05.1991 [Law of Ukraine «On ratification of the Protocol on Pollutant Release and Transfer Registers»]. (n.d.) zakon.rada.gov.ua. Retrieved from: http://zakon5.rada. gov.ua/laws/show/1023-12 [in Ukrainian].

4. Aleksieieva, V. M. (2005). Udoskonalennia upravlinnia komunalnoiu vlasnistiu v Ukraini: orhanizatsiino-teoretychni zasady. Chernivtsi: Tekhnodruk, 216 p. [in Ukrainian]. 
5. Dymchenko, O. V. (2009). Zhytlovo-komunalne hospodarstvo v reformatsiinomu protsesi: analiz, proektuvannia, upravlinnia: Monohrafiia / O. V. Dymchenko; Kharkiv. Nats. akad. misk. hospodarstva. Kh.: KhNAMH. 356 p. [in Ukrainian].

6. Drahan, I. O. (2011). Derzhavne upravlinnia rozvytkom zhytlovo-komunalnoho hospodarstva Ukrainy: modernizatsiia ta resursozberezhennia: monohrafiia / O. Drahan; Nats. akad. nauk Ukrainy, In-t ekonomiky pryrodokorystuvannia ta staloho rozvytku. Donetsk: Yuho-Vostok, 2011. 235 p. [in Ukrainian].

7. Liubchenko, P. M. (2012).Munitsypalne pravo Ukrainy: Navch. posib. I P. M. Liubchenko. Kh.: Vyd-vo «FINN», 496 p. [in Ukrainian].

8. Maliuta O. V. (2010). Udoskonalennia mistsevoho samovriaduvannia u sferi nadannia zhytlovo-komunalnykh posluh: Avtoref. dys.... kand. nauk z derzh. upr.: 25.00.04 / O. V. Maliuta; Donetsk. derzh. un-t upr. Donetsk, 2010. 23 p. [in Ukrainian].

9. Rybachuk, V. L. (2012). Derzhavne upravlinnia sferoiu zhytlovokomunalnykh posluh: kontseptualni teoretychni polozhennia, suchasni mekhanizmy ta napriamy podalshoho rozvytku: Monohrafiia / V. L. Rybachuk; Akad. munitsyp. upr. Donetsk: Yuho-Vostok, 351 p. [in Ukrainian].

10. Sydorova, A. V. (2012). Statystychne zabezpechennia upravlinnia pidpryiemstvamy zhytlovo-komunalnoho kompleksu: Monohrafiia / A. V. Sydorova, I. V. Panasenko; Donetsk. nats. un-t. Donetsk: DonNU, 156 p. [in Ukrainian].

11. Shumilikin, V. A. (2003). Pidvyshchennia efektyvnosti mistsevoho samovriaduvannia $\mathrm{V}$ Kharkovi na osnovi naukovo-tekhnichnoho, sotsialnoekonomichnoho i kadrovoho potentsialu mista / V. A. Shumilkin, V. M. Babaiev, V. I. Luhovyi. Kh., NTU «KhPI», 400 p.

12. Deklaratsiia Orhanizatsii Obiednanykh Natsii «Zahalna deklaratsiia prav liudyny» № 995_015 vid 10.12 .1948 (n.d.) zakon.rada.gov.ua. Retrieved from: https://zakon.rada.gov.ua/laws/show/995_015. [in Ukrainian].

13. Zakon Ukrainy «Tsyvilnyi kodeks Ukrainy» № 435-IV vid 16.01.2003 [Law of Ukraine «On ratification of the Protocol on Pollutant Release and Transfer Registers»]. (n.d.) zakon.rada.gov.ua. Retrieved from:http://zakon5.rada.gov.ua/ laws/show/435-15. [in Ukrainian].

14. Zakon Ukrainy «Kryminalnyi kodeks Ukrainy» № 2341-III vid 05.04.2001 [Law of Ukraine «On ratification of the Protocol on Pollutant Release and Transfer Registers»]. (n.d.) zakon.rada.gov.ua. Retrieved from:https://zakon.rada.gov.ua/ laws/show/2341-14 [in Ukrainian].

15. Zakon Ukrainy «Pro osoblyvosti zdiisnennia prava vlasnosti u bahatokvartyrnomu budynku»: Zakon Ukrainy № 417-VIII vid 14.05.2015 [Law of Ukraine «On ratification of the Protocol on Pollutant Release and Transfer Registers»]. (n.d.) zakon.rada.gov.ua. Retrieved from https://zakon.rada.gov.ua/laws/show/417-19 [in Ukrainian]. 